\title{
Concepción Gimeno de Flaquer. Del sí de las niñas al yo de las mujeres.
}

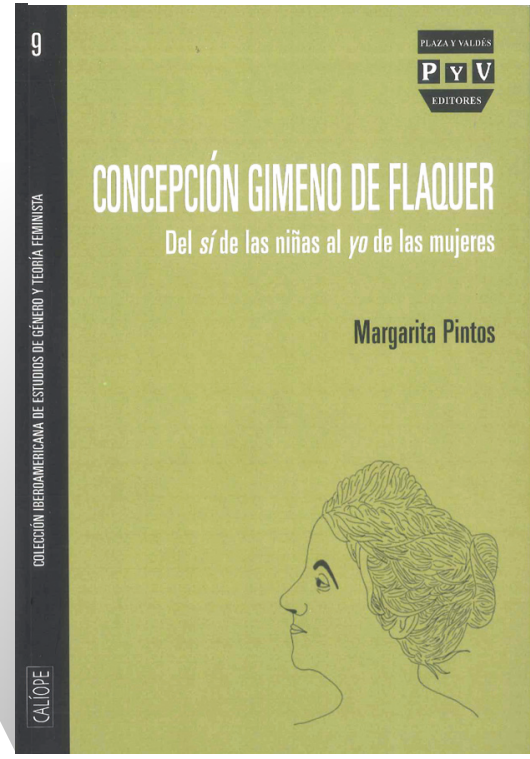

FICHA BIBLIOGRÁFICA

Margarita Pintos De Cea-Naharro, Concepción Gimeno de Flaquer. Del sí de las niñas al yo de las mujeres, Madrid, Plaza y Valdés Editores, 2016, 281 págs. ISBN 978-84-16032-75-4.

\section{Ana Vargas Martínez Universidad Carlos III de Madrid}

Concepción Gimeno Gil (1850-1919) o Gimeno de Flaquer, como habitualmente se la conoce, es una de las mujeres más emblemática del pensamiento español de la segunda mitad del siglo XIX y primeras décadas del XX. Una singular pensadora, escritora, teórica feminista e historiadora de la que, como sucede en otras ocasiones, cabe decir que aún no ha sido suficientemente conocida y valorada. La riqueza de sus ideas, sus escritos, su labor como editora, periodista, conferenciante, luchadora feminista, viajera y, en general, el interés que suscita su vida al completo hace de Concepción Gimeno Gil una figura poliédrica, como así nos desvela Margarita Pintos en el libro que aquí se presenta. Un texto que supone una 
importante contribución al reconocimiento y difusión de la biografía y el legado intelectual de Concepción Gimeno. Autora prolífica de ensayos, novelas, cuentos y cientos de artículos, toda su obra está atravesada por un tema clave: la defensa de la educación de las mujeres. La ausencia o escasez de una adecuada formación para el sexo femenino, de la que directamente culpa a los hombres porque no quieren tener una mujer inteligente a su lado (p. 21), será una cuestión siempre presente en su actividad intelectual. En este sentido, afirma con contundencia "La luz es para todos: nada justifica que se fomente la ceguera intelectual de un sexo" (p. 23). Concepción Gimeno fue una mujer que traspasó los límites de la sociedad patriarcal en la que vivió, situándose por encima de los contenidos de género marcados para las mujeres del momento, y que supo utilizar inteligentemente las posibilidades que le ofrecían su posición social, su exquisita educación y su talento para las relaciones, como se descubre en las páginas de este estudio. Una investigación que Margarita Pintos ha llevado a cabo con minuciosidad, rigor y amplitud de mirada para ofrecer datos y hechos hasta ahora desconocidos, o poco conocidos, sobre una mujer influyente y reconocida en su época, que fue dueña de su vida y actuó son señorío y libertad. Pionera de la conciencia feminista en nuestro país, Concepción Gimeno de Flaquer constituye además un importante eslabón en la genealogía de pensadoras, ensayistas y teóricas feministas que discurre a lo largo del siglo XIX y principios del XX en España.

El libro muestra un interesante y detallado recorrido por la vida y la obra de Concepción Gimeno a lo largo de ocho capítulos que, a su vez, podemos agrupar en dos partes bien diferenciadas. En los cincos capítulos iniciales, que conformaran la primera parte, la autora narra el proceso vital de Concepción Gimeno siguiendo un orden cronológico: sus orígenes familiares, formación intelectual, proyectos, actividades de todo tipo y viajes, entre otros hechos relevantes. En este proceso, sin duda destaca la figura de Francisca Gil Buizá, la madre de Concepción, una mujer culta, valiente, tenaz y decidida, que fue crucial en la vida de nuestra escritora y le sirvió de ejemplo y de guía. Plenamente consciente de la importancia que suponía tener una buena formación, Francisca procuró que así fuera también tanto para sus hijas como para su hijo, sin distinción. En este sentido, podemos decir que el interés de Concepción Gimeno por la educación de las mujeres fue algo que mamó de su madre. Otra figura fundamental para la escritora es la de su maestra, doña Gregoria Brun, a la que elogia y reconoce todo lo que ha supuesto en su vida. Elogio y reconocimiento que extiende a la labor emprendida por las maestras en general, a las que considera la "palanca de Arquímedes".

$\mathrm{Si}$ el derecho de las mujeres a la educación es uno de los pilares fundamentales en su obra, no lo es menos la importancia de conocer la historia de las mujeres y la de reconstruir genealogías femeninas. Otra constante en sus escritos es la aparición de un gran número de mujeres, tanto antecesoras como contemporáneas, a las que cita y ensalza. A lo largo de su vida, Concepción establece vínculos con escritoras, mujeres de la nobleza, de la alta burguesía y pertenecientes a logias masonas interesadas en la cultura. Los datos que aporta en sus textos sobre estas relaciones, de amistad a la vez que intelectuales y políticas, son una importante fuente de información que abre la posibilidad de conocer a otras escritoras españolas de la época y nos da muestra del tejido relacional existente entre ellas. Con el apoyo de algunas 
de estas mujeres, Gimeno crea y dirige revistas como La Ilustración de la Mujer, El Álbum de la mujer o El Álbum Ibero Americano.

Las redes que Concepción Gimeno favorece no se limitan al ámbito español. Al otro lado del Atlántico también encuentra a muchas mujeres para quienes la formación intelectual de su sexo era igualmente una cuestión de primer orden. Así, durante su estancia en México (1883-1890), nuestra autora entrará en contacto rápidamente con los círculos políticos, culturales y feministas del momento. Margarita Pintos describe detalladamente el contexto cultural y social que Concepción Gimeno descubre proporcionando un cuadro pormenorizado de todo ello, así como de las relaciones que establece, básicamente con mujeres masonas. Estas le facilitan la ayuda y el soporte necesario para los viajes que la autora realiza. Uno de los aspectos de gran interés de este ensayo, entre muchos otros, está precisamente en la información que aporta sobre el movimiento feminista en Latinoamérica, cuyo objetivo primordial en esos momentos era la búsqueda de la ciudadanía, lo que suponía no solo el derecho al voto, sino derogar las leyes que situaban a las mujeres como menores de edad jurídicamente, cuestión que Concepción Gimeno de Flaquer denunció en varios de sus textos.

Finalmente, los tres últimos capítulos del libro, que conforman la segunda parte (el aparato crítico), recogen los estudios realizados en los últimos años sobre Concepción Gimeno (lo que se suele entender como un estado de la cuestión) junto con una exhaustiva bibliografía de los escritos de la autora. Un meticuloso trabajo realmente de agradecer a Margarita Pintos pues, entre otras cosas, facilita la labor de quien desee adentrarse en nuevas investigaciones.

El balance crítico de los estudios más recientes llevados a cabo sobre la figura de Gimeno muestra, además, el interés que en los últimos años ha despertado esta autora tanto para la crítica literaria en general, como para la crítica feminista en particular. Interés que muy posiblemente vaya creciendo, pues, en mi opinión, se trata de una pensadora original, difícil de definir de un solo trazo e igualmente difícil de identificar con una u otra corriente feminista. Como afirma Margarita Pintos, Concepción Gimeno representa "el eslabón perdido de una católica marginada por defender el feminismo y de una feminista olvidada por ser católica" (p. 11). Ciertamente, todavía falta mucho por saber, pero sin lugar a duda el ensayo que aquí nos ocupa enriquece el conocimiento y la visibilidad de esta autora. Una mujer que supo vivir libremente, que utilizó siempre la palabra como su herramienta más poderosa para luchar contra la sociedad patriarcal que le tocó vivir, a la vez que para crear una sociedad justa, igualitaria y civilizada, donde las mujeres fueran valoradas y reconocidas, donde la luz fuera para todas y todos. Las páginas de este libro son buen ejemplo de ello. 